\title{
SPIRITUALITY AMIDST THE UPROAR OF MODERNITY: The Ritual of Dhikr and its Meanings among Members of Naqshbandy Sufi Order in Western Europe
}

\section{Widiyanto}

State College for Islamic Studies (STAIN) Salatiga

الملخص

حاولت هذه الدقالة تعبير ملاحظة الكاتب عن طقوس الذكر فى الطريقة النقشبندية

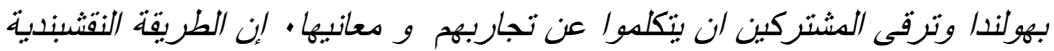

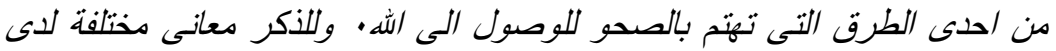

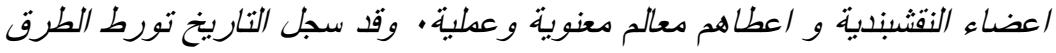

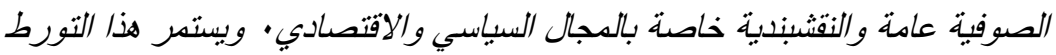

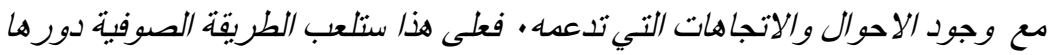
الهام بصفتها شبكة روحبة وسياسية والقتصادية.

\section{Abstract}

Artikel ini dimaksudkan untuk menelaah ritual dbikr dan maknanya di kalangan jamaah Naqshabandy di Eropa. Artikel ini tidak hanya mengungkapkan basil pengamatan semata, tetapi juga mencatat ekspresi pengalaman jamaah sufi dengan bahasa mereka sendiri. Dengan demikian, diharapkan tradisi sufi tidak hanya dipahami sebagai fenomena sosial biasa, tetapi lebih sebagai tradisi yang terus hidup dan berkembang dalam masyarakat. Pada dasarnya, Naqshabandy adalab aliran sufi yang mengutamakan ketenangan dalam menapak jalan menuju Tuhan. Dhikir bagi jamaah Naqshabandy mengandung berbagai makna, baik. yang abstrak maupun yang praktis. Sejarah juga telah mencatat 
keterlibatan kaum sufi, termasuk. Naqshabandy, dalam persoalan politik. dan ekonomi. Ini akan terus berlanjut bila situasi dan kecenderungan kelompok sufi mendukung ke arah tersebut sehingga tidak hanya terkait dengan persoalan spiritual, tapi juga jaringan ekonomi dan politik.

Keywords: Naqshbandy, dhiker, sufi order, shahāda, ḥalāqa

\section{A. Introduction}

The Naqshbandiyya ${ }^{1}$ is one of the most widespread Sufi orders in the world. It exists in such areas as Kurdistan, Afghanistan, Turkey, Syria, Central Asia, Southeast Asia, Pakistan, China, ${ }^{2}$ Egypt, and India. During the past three decades, it has grown extensively in Europe and America alongside such orders as the Shadhiliyya, Chistiyya, Rifa'iyya, and Qadiriyyia. ${ }^{3}$

${ }^{1}$ The name of the order is derived from its founder; Baha' al-Din Naqshband. It means literally one who cast patterns upon cloth. It symbolically signifies the notion of drawing and imprinting God's name upon the heart (See: Nazim al-Haqqani, Mercy Oceans' Hidden Treasures, Konya: Sebat), p.256). It is worth noting, however, that the Naqshbandiyya is not an entirely new order. It stands as a continuation of the orders appearing previous to it in its chain. Hisham Kabbani, in his book The Naqshbandi Sufi Way: History and Guidebook of the Saints of the Golden Chain, (Chicago: Kazi Publications, Inc, 1995), on page 9 designates this chain as the "Naqshbandi Golden Chain". He goes on to relate that from the time of Abu Bakar (d. 634) to the time of Abu Yazid alBistami (d. 875) it was called as-Siddiqiyya. From the period of Tayfur Abu Yazid alBistami to the period of Abdul Khaliq al-Ghujduwani (d. 1179) it was called at-Tayfuriyya. From the time of Abdul Khaliq al-Ghujduwani to the time of Baha' al-Din Naqshband (1317-1388) it was designated as al-Khwajakaniyya. From the time of Baha' al-Din Naqshband to the time of Ahmad al-Faruqi al-Sirhindi (1563-1624) it was known as alNaqshbandiyya. From the period of Ahmad al-Faruqi al-Sirhindi to the period of Khalid al-Baghdadi (1779-1827) it was named al-Naqshbandiyyat al-Mujaddidiyya. From the time of Khalid al-Baghdadi to the time of Ismail al-Shirwani (1787-1840), it was known as al-Naqshbandiyyat al-Khalidiyya. From the time of Ismail al-Shirwani to the time of Abd Allah al-Daghistani (1891-1973) it was al-Naqshbandiyyat al-Daghistaniyya. Currently, it is known as al-Naqshbandiyyat al-Haqqaniyya.

${ }^{2}$ Hamid Algar, "Pengantar", in: Martin van Bruinessen, Tarekat Naqshbandiyah di Indonesia, trans. Ismed Natsir, (Bandung: Mizan, 1992), p. 13

${ }^{3}$ Seyyed Hossein Nasr, "Foreword", in: Hisham Kabbani, The Naqshbandi Sufi Way, p. xxi. 
Many writings have been devoted to study Sufism in the context of Europe. Khalid Duran ${ }^{4}$ gives an interesting account and investigation of European converts to Islam, their attraction to Sufi teachings, and the interaction of these converted Sufis with other non-Sufi Muslim groups. Ottavia Schmidt di Friedberg ${ }^{5}$ has carried out a study about the socioeconomic network built by the Mouride brotherhood in Italy. Pnina Werbner ${ }^{6}$ tries to explore the relationship between the ritual of dhikr and the notion of sacralization of space among Muslims in Britain.

N. Landman ${ }^{7}$ investigates and examines the different roles played by the Sufi orders among various ethnic communities in the Netherlands. W.A.R. Shadid and P.S. van Koningsveld ${ }^{8}$ endeavours to highlight the therapeutic functions played by Sufi orders such as the Qadiriyya. Kamaruddin ${ }^{9}$ and Fakhriati ${ }^{10}$ deal with some aspects of the Naqshbandiyya in The Hague, the Netherlands.

Those researches suggest that it would be of interest to investigate the practice of dhikr and its meanings among the members

${ }^{4}$ Khalid Duran, "Muslim Diaspora: the Sufis in Western Europe", in: Islamic Studies 30, No. 4 (1991), p. 463-483.

${ }^{5}$ Ottavia Schmidt di Friedberg, "West-African Islam in Italy: the Senegalese Mouride Brotherhood as an Economic and Cultural Network", in: W.A.R. Shadid and P.S van Koningsveld, Political Participation and Identities of Muslims in non-Muslim States, (Kampen: Kok Pharos, 1996), p. 71-82.

'Pnina Werbner, "Stamping the Earth with the Name of Allah: Zikr and the Sacralization of Space amongst British Muslims”, in: Barbara Metcalf (ed.), Making Muslim Space in North America and Europe, (London: University of California Press, 1996), p. 167-185.

${ }^{7}$ N. Landman, "Sufi Orders in the Netherlands: their Role in the Institutionalization of Islam", in: W.A.R. Shadid and P.S. van Koningsveld (eds.), Islam in Dutch Societies: Current Developments and Future Prospects, (Kampen: Kok Pharos, 1992).

${ }^{8}$ W.A.R. Shadid and P.S. van Koningsveld, "Religieuze Therapie bij Moslims in Nederland", in: Moslims in Nederland: minderheden en religie in een multiculturele samenleving, (Alphen aan den Rijn: Samson, 1997).

${ }^{9}$ Kamaruddin, "Naqshabandi Sufi Order (Tariqa Naqshabandiyya) and the Implementation in The Hague" (sic), empirical paper submitted to the programme of Islamic Studies Leiden University, (1997).

${ }^{10}$ Fakhriati, "Male outer Appearance as one of Islamic Identities in Naqshabandi Sufi Order: a Case Study of Naqshbandi Group in The Hague" (sic), empirical paper submitted to the programme of Islamic Studies Leiden University, (1997). 
of the Naqshbandy Sufi order in Western Europe. As far as I know, there is no single study which attempts to explore the ritual of dhikr and its meanings among the members of the Naqshbandiyya in Western Europe. In this short essay, I seek to record my observations of the ritual of dhikr in the Naqshbandiyya and allow the participants to speak with their own voices of their experience and of its meanings. This essay, it is hoped, will constitute a contribution in the field of anthropology of religion, especially in the study of Sufism as a vibrant living tradition rather than as a mere historical phenomenon in the context of Europe, the new home of Sufism.

In collecting the data, I have used participatory observation and in-depth interviews. In transliterating Arabic words, I employ the system adopted by many institutions in the Anglo-Saxon world, such as the Library of Congress and the library of McGill University, except try to simplify it by omitting all dots and dashes.

\section{B. Normative Discourse}

\section{The Existence of Sufism and Sufi Orders: Variegated Opinions}

Regarding the existence of Sufism and the Sufi orders, there are at least three different opinions. The first are those adopting a positive opinion to Sufism and Sufi orders, such as Muhammad Hussain Tabataba 1 and Seyyed Hossein Nasr. ${ }^{11}$ The second are those adopting a negative opinion towards Sufism and the Sufi Orders. In the eighteenth century, some of the strongest opponents of Sufism and the Sufi orders emanated from the Wahhabi movement that was developing at that time. Muhammad 'Abduh (1849-1905) was also a prominent figure in attacking Sufism and Sufi orders on the basis that they were full of superstition and fatalism. ${ }^{12}$ His criticism influenced other figures in the so-called Salafi movement in various parts of the Muslim world, such as Musțafā Sādiq al-Rafíi, Shaykh Muhammad al-Ghazāir, alZahrawī, who wrote al-Fiqh wa'l-Tasammuf, and Jamāl al-Dīn al-Qasimì,

${ }^{11}$ See, for instance, his works, Sufi Essays (London: Allen and Unwin, 1972), and Traditional Islam in the Modern World (London: KPI, 1987).

${ }^{12}$ See, for example, his work, Risalat at-Tawhid, (Cairo: Matba'at al-Manar, 1927). 
who wrote Ișlāḥ al-Masäjid mina'-Bidā' wa'l-'Awâ'id. In Egypt, the attack on Sufism came from at least three organisations, i.e., al-Jam'iyyat alShar'iyya (led by Mahmud Khattab al-Subki), Jama'at Ansar al-Sunnat al-Mubammadiyya (led by Hamid al-Fikr), and Ikhwan al-Muslimin (led by Hassan al-Banna). ${ }^{13}$ The third are those who appreciate Sufism, but try to eliminate the ecstatic tendency within it. This grouping is represented by the writings of Muhammad Iqbal and Fazlur Rahman.

\section{The Position of Dhikr among the Sufis}

Among the Sufis, dhiker (remembrance of God) holds an important position. M.R. Bawa Muhaiyaddeen is of the opinion that dhikr is a means of tasting beauty and divine knowledge, and a means to converse with God in a state of total absorption. ${ }^{14}$ Dhikr, in the eyes of Sheikh Ahmad al-Alawi, is the call of the heart, which enables it to attain the divine light. ${ }^{15}$ Idries Shah views dhikr as a means of attaining divine illumination. ${ }^{16} \mathrm{Javad}$ Nurbakhsh is convinced that dhikr, among others, functions to cure the diseases of the self. ${ }^{17}$ According to Abü Hamīd al-Ghazāili (1058-1111), dhikr polishes the heart, enabling it to become a mirror reflecting the divine qualities and attributes. Najm al-Din al-Kubra (1145-1220) says that as the dbikr sinks down into the heart it becomes an interior sob or cry of yearning. ${ }^{18}$ Ubayd Allah al-Ahrāar (1404-1490), one of the Naqshbandy masters, elucidates that

13 See John L. Esposito (ed.), The Oxford Encyclopaedia of the Modern Islamic World (Oxford: Oxford University Press, 1995), specifically his entry under "Sufism", and P.J. Bearman et al (eds.), The Encyclopaedia of Islam, web cd edition, under the entries "Tasawwuf", "Muhammad 'Abduh" and "Salafiyya". See also, Elizabeth Sirriyeh, Sufis and Anti Sufis: The Defence, Rethinking and Rejection of Sufism in the Modern World (excerpts are available online on www.amazo.com/9p/reader/, being accessed on April 4, 2004).

${ }^{14}$ See his book, Islam \&World Peace: Explanations of a Sufi (Philadelphia: The Fellowship Press, 1987), p. 58-60, 104.

${ }^{15}$ See Martin Lings, Syaikh Ahmad al-Alawi: Wali Sufi Abad 20, trans. Abdul Hadi W.M. (Bandung: Mizan, 1989), p. 42-50, 101.

${ }^{16}$ See his book, The Sufis, (London: The Octagon Press, 1977), p. 300-307

${ }^{17}$ Quoted by Ian Richard Netton, Sufi Ritual: the Parallel Universe, (Richmond: Curzon Press, 2000), p. 13.

${ }^{18}$ Michael A. Sells, “Dhikr", in: John L. Esposito (ed.), The Oxford Encyclopaedia, vol. 1, p. 373 . 
dhikr is of importance to control and reduce the turbulence of the heart. ${ }^{19}$

For Nazim al-Haqqani, the Naqshbandi master, dbiker is the medicine and nourishment of the heart, a means of attaining spiritual enlightenment. ${ }^{20}$ Furthermore, he states that the human has two dimensions of being; the physical being and the spiritual being. The spiritual being works by means of heavenly power. Such heavenly power comes to people through dhikr. ${ }^{21} \mathrm{He}$ also asserts that dhikr is of importance for satisfaction in life. It is a source of wisdom and a powerful vehicle for the soul to God. The people of dhikr, for him, dwell in the presence of God and are the repositories of wisdom. ${ }^{22}$

Hisham Kabbani, the representative (khalifa) of grand master Nazim al-Haqqani, explains that one who performs the $d b i k r$ will find peace and satisfaction in his heart and will enhance his spirit, which then enables him to sit in the Divine Presence. Kabbani goes on to explain that "dhiker polishes the heart and is the source of the Divine breath that revives the dead spirits by filling them with the blessings of God, decorating them with His attributes and bringing them from a state of heedlessness to the state of complete wakefulness. If we keep busy with dhikr Allah, happiness and peace will be granted to us. Dhikr is the key to happiness, the key to joy, the key to Divine Love". ${ }^{23} \mathrm{He}$ also asserts that dhiker is a prominent worship, a key to all success and the prevention of hypocrisy. ${ }^{24}$.

In Sufi tradition, there is a close relationship between dhiker and spiritual healing. Nazim al-Haqqani ${ }^{25}$ tries to outline the varieties of illness and ways to cure them. For him, there are many factors behind

${ }^{19}$ Hisham Kabbani, The Naqshbandi Sufi Way, p. 176.

${ }^{20}$ See his book, Mercy Ocean's Divine Sources, (Turkey: Sebat, 1984), p. 44-48.

${ }^{21}$ See his book, Pure Hearts, (London: Healing Hearts/ Zero Productions, 1998), p. 25.

${ }^{22}$ Nazim al-Haqqani, Mercy Oceans: Books Two, (Turkey: Sebat, 1980), p. 190.

${ }^{23}$ Hisham Kabbani, The Naqshbandi Sufi Way, p. 35-37.

${ }^{24}$ Quoted by Ron Geaves, The Sufis of Britain: an Exploration of Muslim Identity, (Cardiff: Cardiff Academic Press, 2000), p. 47.

${ }^{25}$ See his book, Natural Medicines: Traditional Sufi Healing Methods, (London: Zero Productions, 1997). 
illnesses, some are physical and others are spiritual. Therefore in his treatment of illness he employs remedies and dhikr. He likewise asks the patient to pay sadaqa (religious alms).

Hisham Kabbani ${ }^{26}$ asserts that spiritual healing utilizes the latent energy of the patient and the power contained in the devotions and meditations of the holy men. Dhikr or meditation is a means that provides deep relaxation and quiets the mind. This helps to lessen stress, and enables the internal chemical and hormonal system to regain their equilibrium. Furthermore, there is also dhikr for each point of the lat $a^{-}$if (subtleties), which serve to activate the energy of the body. This kind of healing, according to Kabbani, will raise the patient to higher levels of health and spirituality than he previously experienced. This reveals that, at the normative level, dhikrimplies various meanings ranging from abstract ones like spiritual enlightenment to more practical ones like physical healing.

\section{Naqshbandi Mode of Dhikr}

The Naqshbandiyya is one of the Sufi orders that advocate the practice of silent dhiker (dhikr khafi) instead of vocal dhiker (dhiker jahri). Silent dhikr has become the distinguishing feature of the Naqshbandi among other Sufi orders. This silent dhikr, or dhiker of the heart (dhiker qalbi), avoids the use of the tongue and all but the most minimal bodily movements. This mode of dhikr is elaborated --among others-- by Baha' al-Din Naqshabandy; ${ }^{27}$ who claimed to have been initiated by the spiritual being of Abdul Khaliq al-Ghujduwani. There are also a number of branches of the Naqshbandiyya practicing vocal dhiker, either exclusively or in conjunction with silent dhikr. However, the major reformers of the Naqshbandi tradition, such as Ahmad al-Faruqi alSirhindi, and Khalid al-Baghdadi (d. 1827 AD) always reaffirmed the

${ }^{26}$ Hisham Kabbani, "Spiritual Healing in the Islamic Tradition", http://www. naqshbandimuhibbeen.com, being accessed on August 10, 2004.

${ }^{27}$ See, for instance, Abd al-Qadir ibn Muhammad Abu Nur al-Kayyali, al-Fuyudat al-Ihsaniyy Sharh al-Awrad al-Baha'iyya, (Egypt: al-Iskandariyya, 1289/1872). Baha' alDin argues that he prefers the silent $d h i k$ r because it is stronger and hence more excellent; Hisham Kabbani, The Naqsbbandi Sufi Way,p. 7. 
excellence of silent dhikr. ${ }^{28}$ Muhammad Amin al-Kurdi (d. $\left.1332 \mathrm{AH}\right){ }^{29}$ explains that silent dhikr is classified into two; bi-ism al-dhat (by the name of the Essence; "Allah") ${ }^{30}$ and bi'l-nafy wa'-ithbät' (by negation and affirmation; "là iläha illa'l-Läb").

\section{The Ritual of Dhikr in the Naqshbandy Sufi Order in Western Europe}

This research focuses on the practice of dhikr among the members of Naqshbandi Sufi order in the Netherlands and Germany. As for Germany, I observe and participate in the dhiker that was intended as a gathering for the Naqshbandis in Western Europe.

In Delft, the Netherlands, the collective dhikr is held every Friday at about 08.00 p.m. in the home of the sheikh. In the winter it is usually held on Thursday after the maghrib prayer. The members sit around

${ }^{28}$ For further explanation of these two types of dhiker, Hamid Algar, "Silent and Vocal Dhikr in the Naqshbandi Order", in Akten des VII Konggresses fur Arabistik und Islamwissenchaft, (Gottingen: Vandenhoek \& Ruprecht, n.d.), p. 39-46; Isenbike Togan, "The Khafi, Jahri Controversy in Central Asia Revisited", in: Elizabeth Ozdalga (ed.), Naqshbandis in Western and Central Asia: Change and Continuity, (Istanbul: Swedish Research Institute in Instanbul, 1999), p. 17-46.

${ }^{29}$ See his book, Kitab Tanwir al-Qulub fi Mu'amalat 'Allam al-Ghuyub, (Surabaya: Shirkah Bungkul Indah, 1980), p. 508-516. See also his book, Kitab al-Mawabib alSarmadiyya fi Manaqib al-Naqshbandiyya, (Cairo: Matba'at al-Sa'ada, 1329 H), p. $309 \mathrm{ff}$.

${ }^{30}$ There is also an explanation from Muhammad Wali al-Khalidi on this kind of dhikr, see Inilah Risalat Adab Dhikr Ism al-Dhat dalam Tariqat Naqshbandiyya, (Aceh: Shirkat Banda Aceh, 1900). Zawwar Husayn, in his 'Umdat al-Suluk, as Arthur F. Buehler (p. 127) puts it, states that the sheikh activates the latifa of the heart by putting his four fingers in the locus of the heart, the latifa. He puts pressure on this place and says "Allah" three times while transferring a spiritual energy to the heart of the disciple. By this process, dhiker bi-ism dhat is imparted to the disciple.

${ }^{31}$ Muhammad Amin al-Kurdi, Al-Ijabat al-Rabbaniyya, (Cairo: Matba’at al-Sa'ada), p. 39. Muhammad ibn 'Abdillah al-Khani al-Khalidi, in his book, al-Babjat al-Saniyya fi Adab al-Tariqat al-'Aliyyat al-Khalidiyyat al-Naqshbandiyya, ((Cairo: al-Matba'at al-Maimana, 1319), p. 49), elucidates that there are conditions of dhikr bi'-nafy wa'l-ithbät, firstly, restraining one's ego, secondly, reciting "là iläha illa Allāb", thirdly, witnessing the engraving of Allah's name on the heart (naqsh), fourthly, paying attention to the meaning, fifthly, pounding, sixthly, awareness of the heart to the point of totality, seventhly, awareness of the numbers, eighthly, reciting “Muhammad Rasül'-Läh", lastly, returning to God by reciting "Ilābi anta maqsüdì wa riḍ̄ke mațübì". 
chatting or greeting friends until, at a signal from the sheikh, they arrange themselves in the positions prescribed for the dhikr, i.e. in the form of a circle (baläqa). The haläqa of women is separated from the haláqa of men. On the meaning of haläqa, the sheikh said, "When the people make a baläqa to perform dhikr, the angels also make ḅalaqa till the seventh heaven. The halaqqa should be perfect; there is no hole, so then satan can not enter." When a member comes late, other members give space to him. About twenty persons participate in the dhikr. To make the environment appropriate for $d h i k r$, fragrances are also used. ${ }^{32}$

The sheikh begins with collective dhikr, which is called khatm alkhwajakan, ${ }^{33}$ by instructing the people to concentrate on their heart. It is suggested that the participants of the dhiker close their eyes. ${ }^{34} \mathrm{He}$ pleads for the succour and assistance of the grand sheikh by saying "madad ya sayyidi, madad ya mawlana". He and the members then recite the shahada (profession of faith) and istighfär (request for God's forgiveness). They make the rabita (spiritual connection) to the grand sheikh by imagining the picture of him in their mind. Then they continue reciting some chapters of the Koran (al-fatiha, al-ikbläs, al-falaq, and

32 A respondent explained that they often use musk (misk) to perfume the location of the dhiker. For Muslims, perfume has a religious significance, namely the attraction of good souls. This conviction owes its origin to the prophetic tradition stating that fragrant smells are loved by the angels while unpleasant odours are loved by the devils.

${ }^{33}$ The sheikh of Delft said that the word originates from Persian; means the closing of the meeting by the sheikh (khwajakan means sheikhs). Muhammad Amin al-Kurdi (Tanwir al-Qulub, p. 520-523), explains that this dhikris called khatm (closing), because when the murids were gathering around the sheikh, and he wanted the murids to leave, he closed the meeting with this dhike. This kind of dhikrwas formulated by Abd al-Khaliq al-Ghujduwani. Muhammad Amin al-Kurdi discloses this kind of dbiker in his book. In general, this is what is implemented in the Naqshbandi Sufi order in Delft, although with some variations. One publication makes the point that the khatm alkbwajakan is regarded as the third pillar of the Naqshbandi after dhikr bi-ism dhat and dhiker bi al-nafy wa al-ithbat (Martin van Bruinessen, Tarekat Naqshbandiyah, p. 85).

${ }^{34}$ The instruction to close the eyes when performing dhiker comes from such Naqshbandi books as Amin al-Kurdi's Kitab al-Mawabib al-Sarmadiyya, p. 320 and alIjabat al-Rabbaniyya, p. 37, and Sulayman al-Baghdadi, al-Hadiyyat al-Nadiyya fi Adab alTariqat al-Naqshbandiyya wa al-Babjat al-Khalidiyya, (Cairo: Matba'at al-Ma'ahid, 1925), p. 136-137. 
al-nās), salawat (phrases of eulogy to the prophet), and $d u^{\prime} a$ (prayer) for the Naqshbandi masters and the people of khatm al-khwajakan.

The sheikh recites the phrase "la iläha illa"l-Läb" and the rest of those performing the dhiker follow for a certain period of time. Their heads move in accordance with the rhythm of the dhikr. They then chant the word "Allah", sometimes in a soft voice, with violent expulsions of breath on the last syllable, then in a medium and then in a raised tone. We observe that they perform a rocking movement in unison. When they have concluded reciting "Allah", the Sheikh then directs the group to other glorious names; "Huwa" (the word, in fact, is intoned as a long "Hu", the last syllable, "wa", is unpronounced), "Haqq", and "Hayy", 35 in the same rhythm, and closing with the phrase "basbuna'l-Läh wa ni'ma'l-wakil". ${ }^{36}$ The sheikh and the members then say "hoooo...." 37

After this, the group recite some of His most beautiful names (al-asmä' al-ḥusnā) such as Haqq, Hayy, Qayyūm, Dā’im, Hāim, Hāfiz, Laṭif, Ghaffār, Sattār, Fattāh, Mujīb, Mu’in, Wadūd, Raḥmān, Hannān, Mannān, Dayyān, Subḥān, and Sulțān, although not in the same frequency and intensity as before, and close it with the phrase "basbuna"l Läh wa ni'ma'l-wakip'. The khatm al-khwajakan closes with saläwat and $d u^{\prime} a$, calling upon God to bless the prophet, the righteous caliphates,

${ }^{35}$ According to Michael Gilsenan (Saint and Sufi in Modern Egypt: An Essay in the Sociology of Religion, (London: Oxford University Press, 1973), p. 167-168.), the significant characteristic of the names of God being chanted with a special rhythm ("Huwa", "Hayy", "Haqq", and "Qayyum"), is that they are the names which focus on the transcendence and power of Allah. In other words, they are the most essential of the names. The words being chanted are inherently sacred. They impose sanctity to the ritual, rather than being sanctified by it. The condensation of energy or the power of the words in the rhythmic proclamation of the transcendence of God is a key to the incredibly emotional effervescence of the dhiker.

${ }^{36}$ A respondent said that this phrase means that they praise God for the ni'ma (grace) and tranquility they receive through the dhikr. It also means than they should find sufficiency with this ni'ma, and not let themselves to be in a state of jadbba (excitement).

${ }^{37}$ A respondent asserted that this signals exhalation. This shows that the Naqshbandiyya pays attention to breathing, and relates the reciting of the name of God with the act of breathing. 
Naqshbandi masters, and the people of khatm al-khwajakan. After that they recite "innā li'-Lāh wa innà ilayh räji'un". ${ }^{38}$

As for individual dhiker, the sheikh of Delft explained that the members of the Naqshbandiyya in the Netherlands use as a reference the booklet of Naqshbandi dhiker published by the secretariat of the Naqshbandiyya in The Hague. ${ }^{39}$ The explanation of dhikrin this booklet is similar to that of Kabbani's The Naqshbandi Sufi Way. When we examine this booklet's exposition concerning individual daily dhikr, we become aware that they also use vocal dhikr, particularly for beginners. The intermediate aspirants employ both vocal and silent dhikr. They recite "Allah" 2500 times with the tongue and 2500 times with the heart. The advanced disciples also use both vocal and silent dbikr. They recite "Allah" 5000 times with the tongue and 5000 times with the heart.

The large scale dhikr in Germany is intended as a gathering for the Naqshbandis in Europe. It takes place in a zawiyy ${ }^{40}$ called Osmanische Herberge. In this meeting, Sheikh Hassan Dyck, the representative of Grand Sheikh Nazim al-Haqqani leads the dhikr, while other (local) sheikhs sit beside him facing the members. Because of a shortage of space, the members sit in line, forming saff instead of b.alaqa. The saff of women is separated from the saff of men. About two hundred people participate in this dhikr. The number of women is almost the same as the number of men.

In general, the performance of dhikr in Germany is almost the same as that in Delft. The dhiker is held after the maghrib prayer on a Sunday once a month. Before starting the dhikr, all lights are turned off with the exception of one lamp; the room thereby becomes blurred. They intone the phrase "lā iläha illa'-Läb" with steadiness and serenity for a longer period than I observed in Delft. The steadiness and touch of the voice of Sheikh Hassan influence the atmosphere of the dhikr.

${ }^{38}$ A respondent said that this is in accordance with Sufi teaching, "Mutu qabla an tamutu" (Die before you die). Following the Sufi path means killing one's ego to live in God's eternity.

${ }^{39}$ See: De Naqshbandiya Awrad, (Den Haag: Secretariat van de Naqshbandiya, 1998).

${ }^{40}$ Zawiya is a place of Sufi learning and gathering. 
The dhikr is accompanied by the sound of a flute, then by the sound of drum. ${ }^{41}$ They chant the words "Huwa", "Allah" and "Hayy" steadily. The situation is contemplative; the drummer seems to be in ecstasy. They also chant the words "Ya Wadud", "Ya Latif", and "Ya Qayyum" in the same rhythm, longer than that observed by me in Delft. One of the (local) sheikhs recites some verses of the Koran. The dhikr is closed with a $d u^{\prime} a$ by another (local) sheikh. At this point, we become aware that despite the use of music, an atmosphere of sobriety is emphasised.

In general, the performance of dhikr in Rotterdam, The Netherlands is almost the same as that in Delft. The dbiker is held in the mosque after the Maghrib prayer. All the lamps are turned off, and fragrances are used. Before the dhikr, the sheikh gives a brief oration on qalb (heart), nùr (light), Nür Muhammad (Muhammadan Light), and three steps of fanä, namely, fan $\bar{a}$ ' fi al-shaykh (annihilation in the sheikh), fanà' fi rasül Allab (annihilation in the prophet), and fan $\bar{a}^{\prime}$ fi Allăh (annihilation in God). They offer $d u^{\prime} a$ for the Naqshbandi masters, the people of khatm al-khwajakan, and Jalāl al-Dìn Rümìi.

The sheikh and the members say "hooo...hooo...." After that they begin to chant the phrase "la ilaha illa 'llah" beginning slowly, then adopt a medium tempo and after that a quickening one. In the mean time there is a dervish wearing a black dress - called the semazenbashi (dance master) - who bows to the sheikh and kisses his hands. He whirls for a moment, then he prostrates. Two dervishes wearing white dress continue the whirling. Before commencing the whirling they bow to the sheikh and kiss his hands, and remove their cloaks. ${ }^{42}$ With arms folded in front of their chests, they walk to the centre of the circle (balaqa), reciting dbikr as they turn. They empty their hearts of all but Allah and whirl in ecstatic movement and rhythm. Should a dervish become tired, he may restrain from the whirling and stand at the side of the circle while the other whirls. He can rejoin the

${ }^{41}$ The melody and harmony function to stimulate psychological and emotional effervescence. They are more beautiful than speech, are absorbed faster into the heart, and are more effective to the mind and the community of the hearts (Michael Gilsenan, Saint and Sufi in Modern Egypt, p. 169).

${ }^{42}$ It is said that removing the cloak is a symbol of leaving worldly attachment and preparing to return to God. 
whirl when he wishes to. The sheikh and the members begin a softly breathed repetition of "Allah" which becomes louder and more violent till their mouths reflectively and unconsciously chant the word, and conclude it with the phrase "Whasbunäl-Läh wa ni'ma"-wakil".

When they have finished a period of recitation of one of the radiant and glorious names, he transfers them to others; "Huwa" (the word is intoned as a long "Hu" ${ }^{43}$, "Haqq", "Hayy", and "Qayyum", in the same rhythm. When they shout the words "Haqq" and "Hayy" in a raised tone, the sounds resemble the call of a bird. ${ }^{44}$ After shouting each of these words they close it with the phrase "hasbunā 'llāh wa ni'ma '-wakip'. The dhikris closed by salawat and du'a. Then they perform the Isha' prayer. After prayer they stand and form a circle. One of the dervishes recites saläwät and poetry in Persian.

\section{The Meaning of Dhikr among the Members of the Naqshbandi Sufi Order}

Sheikh Nazim al-Haqqani said that he was sent to the West by his master, Sheikh Abd Allah al-Daghistani, to anticipate what was foretold in the hadith, "The sun will rise from the West". His aim, then, is to awaken new spirituality in the West. For him, Islam gives and offers greater spirituality to the hearts of people than any other religion. ${ }^{45}$ Sufism, in general, and the Naqshbandiyya, in particular, thus endeavours to provide spirituality to those who are thirsty. It is gaining increasing acceptance and is considered as one of the wellestablished orders in the West.

A respondent said that in the Naqshbandi zamiya in Cyprus, the homeland of the grand master, three to five persons embrace Islam

${ }^{43}$ According to Michael Gilsenan (Saint and Sufi in Modern Egypt, p. 187), when "Huwa", the most essential name, is intoned, it is indistinguishable from the symbol of power and life that delivers it, the breath, and men can thereby experience the unity of what is beyond and within.

${ }^{44}$ From this, it can be seen why the Koran states that every creation makes a tasbih (glorification) to God, and why for the Sufis the bird is an allegory for the seeker of God.

${ }^{45}$ Sheikh Nazim al-Haqqani, Pure Hearts, p. 7-8. 
everyday. When I attended the large scale dhikr in Germany, three individuals embraced Islam. Sheikh Hassan Dyck (his father is German and his mother is Dutch) certainly attracts Europeans to enter Islam. A respondent, a new convert to Islam, said that he read Sufi books written by Idries Shah. He was attracted to his explanation of the tranquillity of the heart, and of the Koran as one of the sources of this tranquillity. Then he read the Koran, became interested in its message, and became Muslim. He was attracted to being initiated as a Naqshbandi disciple in order to receive spiritual guidance from the Sheikh. He wanted to know what sort of Islamic books should be read. He liked the dhikr very much because it made his life more meaningful.

\section{The Function of Dhikr}

As for the communal dhiker, the sheikh of Delft said, "It is different from individual dhiker because friends strengthen its aura and environment, they help each other. The communal dhikr functions to provide extra energy and power every week as a stock of energy for the week, and as a supply for the making of daily dhikr. The function of daily dhiker is to maintain the energy we get from the collective dhikr." From this point of view, we can understand why there are daily $d h i k r$, weekly dhikr, and monthly dhikr. It is in the collective dhikr that the aspirants feel the unity and strength of the order most strongly.

The function of dhikr, according to the sheikh, is to give tranquillity to the heart, as stated in the Koran, "ala bi-dhikri'-Lāh tatma'innu'l-qulüb" (verily it is by remembering God that the heart will be peaceful). Furthermore, he explained that, "By dhiker we want to be nothing. Other people may want to be whatever, but we want to be nothing. In order to be nothing, we have to kill our ego, because we can not serve two gods." This shows that the Naqshbandiyya emphasize humility and contemplative practice.

A respondent, who had been following the Naqshbandiyya for two years, said, "Dhiker is my oxygen, my transportation, like Aladdin's flying carpet, to get Allah's mercy." Another respondent of five years experience in the Naqshbandiyya, said that dhikr is for him a source of energy. Another respondent, who had made a journey through Indian 
and Christian mysticism and finally embarked on Islamic mysticism, asserted, "dhiker is a source of energy, which can be compared with the doctrine of meditation and cakra in Hindi mysticism. Sheikh Hisham Kabbani has elaborated such a thing within the framework of Islamic mysticism." It seems that he is more inclined to contemplative practice, the achievement of peace and tranquillity. Another respondent elucidated that dhikr makes him powerful, since it feeds and strengthens the soul. For another respondent, the Koran as well as the salawat touch the heart, can enhance one's spirituality and make one more alive. He often listens to salawwat from cassettes or compact discs when driving his car.

A respondent said that dbikr can also heal our physical illness. One day he told the sheikh that he suffered from liver trouble. The sheikh then made a special du'a for him while touching his body. The sheikh suggested preparing a bottle of water for the collective dhikr. The sheikh stressed that it would be better for him to also perform daily dhikr and salawwat (hundreds or thousands, the more the better). He then mixed this water with other water and drank it. After about three months he recovered from his illness. Another respondent said that he suffered from asthma. He then drank the water of dbikr and also paid sadaqa. After several weeks he recovered from his illness. When I attended the dhikr I saw some bottles of water in front of the sheikh. A respondent said that he often brought water for the dhiker because it was very useful for his physical and spiritual health.

\section{Sobriety and Ecstasy}

The orientation of dhikr in Delft is to dawam al-dhiker (the persistence of dhikr). The most suitable for this kind of dhikr is silent dhike, for it can be performed any where. The sheikh of Delft, like other Naqshbandi sheikhs, underlines the eminence of silent dhiker over vocal $d h i k r$. He analogizes silent $d h i k r$ with fasting in secrecy. It enables us to be with people while our heart is with Allah. A respondent said that the Naqshbandiyya is basically based on silent dhikr. The Naqshbandiyya in Syria fostered silent dhiker, using gravel instead of the rosary. The Naqshbandis are now using vocal modes of dhikr in gatherings in order to attract people. Another respondent said that 
ecstasy is not the aim of the Naqshbandiyya, rather it is achieving peace and tranquillity of the heart.

The sheikh of Delft, who has for twenty years followed the Naqshbandi Sufi path, said, "Ecstasy is not the aim of the dhikr, because it is often a call of the ego rather than a call of the pure heart. Allah does not want his servant losing his consciousness. Therefore we should maintain our heart with Allah although we stand in a crowd of people." Nevertheless, he admitted that there are such persons, examples are Jalāl al-Din Rūmì and al-Hallāj, who can attain (real) ecstasy. For him, "ecstasy could be an expression of ego and an expression of unity. AlHallaj's ecstasy is an expression of unity. This was apparent when he was killed, his blood embodied the phrase ana al-Haqq."

The whirling dervish, according to one respondent, is "from the tradition of the Mevlevi. Jalāl al-Din Rümi, the founder of the Mevlevi tariqa, whirled when he heard the spiritual music. Such a holy man can truly achieve ecstasy. He whirled and his body floated between the world and heaven. Recent whirling dervishes are a sort of nostalgia. They can not achieve such a state as Rumi did." For the Naqshbandiyya, ecstasy is not the aim, rather it is tranquility of the heart. When I asked him why Sheikh Hassan Dyck held a performance of whirling dervish such as that seen in the pamphlet, ${ }^{46}$ he said that it was to attract people and non-Muslims to enter Islam and Sufism. In line with this standpoint, the sheikh of Delft said, "The aim of whirling dervish is to attract people. It is from the tradition of Mevlevi. Sheikh Hassan Dyck borrows it as a show for the people because people like to watch a performance, a show, like kung-fu, judo, and so forth."

A respondent correlated the whirling dervish to a shamanic performance. For him, dhiker is one's individual affair with God, and does not require external display. He is unsure about ecstasy; perhaps it is possible to attain, but the aim of dhiker is to achieve tranquility, not to attain ecstasy. Sheikh Hassan Dyck, he said, held the performance of whirling dervish only to attract non-Muslims, it was not his genuine intention. In his eyes, the important thing in life is to

46 "Die Karawane der Liebe: Weisheit und Extase der Sufis" which announced the performance of whirling in $\mathrm{K} \ln$, September 11, 2004. 
love Allah and the prophet. Dhiker, he explicated, can enhance his love of Allah and the prophet.

Another respondent said, "Dervishes had their own time. The time of dervishes is over. Jalāl al-Din Rümi is a holy man therefore he can float between the earth and heaven. Ecstasy does not need to be shown. If one shows his ecstasy, the ego and satan will interrupt it. One's ego drives him to be something, while we should be nothing. The most important thing to do is to observe oneself and not to observe other people." He admitted that he once achieved ecstasy. To achieve such a state, according to him, one has to pay sadaqa, clean oneself, read and feel the Koran and the salawwat. The role of Sheikh, for him, is to help students to connect with Allah in dhiker according to their own stages. When he attended the large scale dhiker in Germany, he was crying, and did not want to come back, because he felt so much happiness and tranquility in Germany.

A respondent from England who has followed the Naqshbandi Sufi path for two years said about the sheikh of Rotterdam, "I know the Sheikh. He teaches people from the United Kingdom and the Netherlands how to whirl. Some non-Muslims are attracted to this activity. Some of them become Muslim, and the rest remain in their religion. They are interested in whirling because they feel such a spiritual connection during the whirling." This reveals that some people in the West are attracted to the mode of spirituality offered by the Naqshbandiyya-Mawlawiyya, particularly to the spiritual experience during the whirling. A respondent, a member of the NaqshbandiyyaMawlawiyya in Rotterdam, said that he feels something like an accumulation of concentration during the whirling. Another member in the same city explained that he feels as if Rumi touches his shoulders when he whirls. He feels his body and heart become warm.

\section{The Sheikh and His Place in the Dhikr}

The (grand) sheikh has a special place in the heart of the Naqshbandis. A respondent said that he met Sheikh Nazim al-Haqqani twice in the Netherlands. He observed him to be a simple person. One day he visited the Sheikh in Cyprus, and stayed there for three days. On the third day he said to the Sheikh that he wanted to leave. On his 
arrival home, he cried, wanting to go back to Cyprus. After that experience, he has felt more tranquil when performing the dhikr. One day, the sheikh of Delft visited Sheikh Nazim al-Haqqani in Cyprus and stayed there for three days. On the third day he wanted to leave and said to Sheikh Nazim, "You are not the right teacher". Arriving home, he cried; his heart was touched. Another respondent said that he also felt nothing when visiting Sheikh Nazim in Cyprus. But after gazing into each other's eyes, he felt different; there was a sort of peace in his heart.

Another respondent said that Sheikh Nazim al-Haqqani is a humble person. If one did not know his identity, he would appear as an ordinary person; he does not look like one possessing high spirituality. Connection to the Sheikh, according to him, is possible either in a dream or in meditation. He once connected to the Sheikh, although not clearly. This reveals that connection and asking for assistance to the Sheikh (rabita) are important parts of $d b i k r$. One should imagine the face of the Sheikh when one asks for assistance in applying more concentration in the dhiker and for elevation to the higher state. Therefore when one performs dhikr, they usually recite the phrase "madad ya mawlana madad ya sayyidi". Visiting the Sheikh is one means of becoming more connected to him while performing dhikr. It is of interest to know how a member of the Naqshbandiyya describes his experience in visiting Cyprus and attending dhikrthere. A respondent told me:

For the Thursday evening khatm, Sheikh Nazim looked at everyone and then asked Sheikh Hisham to lead dhikr. Everyone enjoyed what was one of the most ecstatic dhikers I have ever attended. We were sitting performing $d h i k r$ as if we were transported to a spiritual location and setting in which time slowed and it was as if we were hearing not only the dhikr but the tasbïh of the mala'ika. It was unforgettable. The perfume of that wonderful dhikr left us in a state of lightness. The next day was Friday and I had to leave, but I left feeling as if I had entered paradise with one foot and now had to leave it and return to this earth.

\section{Dhikr, Spirituality, and the Betterment of Society}

Among the Naqshbandi members, participating in the dhikr relates to their motives. Such variegated individual motives can meet in that 
single occasion. Some relate to "religious" motives, and the rest are best described as "worldly" motives. As for religious motives, we can mention the desire to enhance one's spirituality and piety. As for more profane motives, we can refer to the wish to gain blessing (baräka) for his/her livelihood. Some members stated that they were interested in the dhiker and the Naqshbandiyya since they can increase their relations which are useful for their economic activities. This becomes clearer when we observe the large scale dhiker in Germany; some members use that occasion to build some relations, even use it for trading some goods.

When we observe the occupation of the member of the Naqshbandiyya in the Netherlands, we begin to realize that they serve at different positions: workers, traders, entrepreneurs, civil servant, house holders, and students. They remain doing their jobs while they are active in Sufi gatherings. When I asked a member of the Naqshbandiyya, why he does not leave his job in order to be more active in Sufi gatherings, he replied that Sufism and worldly involvement are not contradictory.

The relationship between Sufi order and politico-economic aspects are salient. Many experts have shown the involvement of Sufi order in political domain, as we can see in the case of the revolt of the Naqshbandiyya in Banten, Indonesia. We are also aware of the economic significance of the Sufi brotherhood. When we read Islamic history, we become aware that some orders are closely related to trade guilds. Having realized the politico-economic significances of the Sufi orders in the past, I think it is possible to revive those significances in contemporary world. The Naqshbandiyya, one of the largest Sufi orders, can lead the way for such duty. It is our expectation that Sufi orders will continue in contributing to the betterment of society.

\section{E. Concluding Remarks}

These findings allow us to conclude that the Naqshbandiyya is basically a Sufi order which maintains sobriety in stepping along the path to God. If we use Chittick's classification of Sufism, the Naqshbandiyya is more aptly described as a representative of the so- 
called "sober Sufism" rather than "drunken Sufism". ${ }^{47}$ The Naqshbandis try to minimize the excitement (ibtizaz, jadbba) for the reason that it is not essential. The most essential element, for them, is fana' fi Allah, which is achieved by progressing through fan $\vec{a}$ fi al-shaykh and fan $\vec{a}$ ' $\vec{\imath}$ rasul Alläh. Fanä' for them is one's individual affair with Allah, and need not to be displayed. This reveals that the Naqshbandiyya basically maintains a spirit of humility and rejects ostentation. The Naqshbandiyya in Rotterdam is a unique group. It is a kind of blending between the tradition of the Naqshbandiyya and the tradition of the Mawlawiyya. At different times they call themselves the "NaqshbandiMawlawi", "Haqqani-Mawlawi", or "Naqshbandi". The tradition of the Naqshbandi is still dominant in this group. When making rabita and $d u^{\prime} a$ they still mention the silsila of Naqshbandi masters besides mentioning one single Mawlawi master, i.e. Jalāl al-Din Rūmi. ${ }^{48}$ This group takes the tradition of whirling from the Mawlawiyya. In their dhikr, they seem to be more ecstatic than the group in Delft.

Dhiker implies various meanings for the members of the Naqshbandiyya in the Netherlands. It renders them with abstract as well as practical meanings. As for practical meanings, some of the members see the dhikr as something that can be used in healing physical illnesses, and others perceive it as a means to attain baräka for their livelihood. Some members do not see the dhikr as religious occasion per se but as of those having socioeconomic significances. As for abstract meanings, some of the members correlate it with the attainment of a meaningful life, some with the enhancement of spirituality, others with love for God and the prophet, and some with spiritual energy. It is

\footnotetext{
${ }^{47}$ William C. Chittick, "Sufi Thought and Practice", in: John O. Voll (ed.), Oxford Encyclopaedia, vol. IV.

${ }^{48}$ The sheikh of Rotterdam said that he had a vision. In his vision, he saw Jalal al-Din Rumi bringing the book of lights coming from behind the "Golden Veil". Rumi said to him that Sheikh Nazim al-Haqqani is now the greatest secret from behind the "Golden Veil". It seems that the Sheikh of Rotterdam wishes to pursue a different tradition from his grand sheikh, Nazim al-Haqqani (who has authority on both the Naqshbandiyya and the Mawlawiyya) and blend it with the tradition of the Naqshbandiyya. Such a combination is not surprising in the Sufi world. In Indonesia, for instance, there is a blend between the Qadiriyya and the Naqshbandiyya, namely, alTariqat al-Qadiriyyat wa al-Naqshbandiyya.
} 
worth mentioning that almost all respondents affirmed that dhikr has the capacity to give peace and tranquility to their heart. Connection and asking for assistance to the Sheikh are considered to be important parts of dhikr. Visiting the Sheikh is one means of becoming more connected to him while performing dhikr.

The history has shown the involvement of Sufi order, in general, and the Naqshbandiyya, in particular, in the politico-economic domain. Such involvement can continue if the conditions and tendencies of the order say so. If this becomes the case, the Sufi order will regain its role as spiritual as well as politico-economic network. 


\section{BIBLIOGRAPHY}

Algar, Hamid, "Pengantar", in: Martin van Bruinessen, Tarekat Naqshbandiyah di Indonesia, trans. Ismed Natsir, Mizan, Bandung, 1992.

-, "Silent and Vocal Dhikr in the Naqshbandi Order", in Akten des VII Konggresses fur Arabistik, und Islamwissenchaft, Vandenhoek \& Ruprecht Gottingen, n.d.

'Abduh, Muhammad, Risälat al-Tawhỉ, Mațba'at al-Manar, Cairo, 1927. Al-Baghdady, Sulayman, al-Hadiyyat al-Nadiyya fi Adab al-Tariqat alNaqsbbandiyya wa al-Bahjat al-Khalidiyya, Maṭba'at al-Ma'āhid, Cairo, 1925.

Bearman, P.J. et al (eds.), The Encyclopaedia of Islam, web cd edition.

Blaschke, Jochen, et al (eds.), Muslims in Europe: a Bibliography, Parabolis, Berlin, 2002.

Bruinessen, Martin van, Tarekat Naqshbandiyah di Indonesia, trans. Ismed Natsir, Mizan, Bandung, 1992.

De Naqshbandiya Awrad, Secretariaat van de Naqshbandiya, Den Haag, 1998.

Duran, Khalid, "Muslim Diaspora: the Sufis in Western Europe", in: Islamic Studies 30, No. 4 (1991).

Esposito, John L. (ed.), The Oxford Encyclopaedia of Modern Islamic World, Oxford University Press, Oxford, 1995.

Friedberg, Ottavia Schmidt di, "West-African Islam in Italy: the

Senegalese Mouride Brotherhood as an Economic and Cultural

Network", in: W.A.R. Shadid and P.S van Koningsveld, Political

Participation and Identities of Muslims in non-Muslim States, Kok Pharos, Kampen, 1996.

Geaves, Ron, The Sufis of Britain: an Exploration of Muslim Identity, Cardiff Academic Press, Cardiff, 2000.

Gilsenan, Michael, Saint and Sufi in Modern Egypt: An Essay in the Sociology of Religion, Oxford University Press, London, 1973.

Al-Haqqani, Nazim, Mercy Oceans' Hidden Treasures, Sebat, Konya, n.d. 
—, Mercy Oceans' Divine Sources, Sebat, Konya, 1984.

—, Mercy Oceans: Books Two, Sebat, Konya, 1980.

-, Natural Medicines: Traditional Sufi Healing Methods, Zero Productions, London, 1997.

—, Pure Hearts, Healing Hearts/ Zero Productions, London, 1998.

Kabbani, Hisham, The Naqshbandi Sufi Way: History and Guidebook of the Saints of the Golden Chain, Kazi Publications, Inc, Chicago, 1995.

_, "Spiritual Healing in the Islamic Tradition", (Online), (http:/ /www. naqshbandimuhibbeen.com, being accessed on August 10, 2004).

Al-Kayyāly, Abd al-Qādir ibn Muhammad Abū Nūr, al-Fuyūdat alIḅsāniyya Sharh al-Awrad al-Babä'iyya, al-Iskandariyya, Egypt, 1289/ 1872.

Al-Khalidy, Muḥammad ibn 'Abdillāh al-Khāny, al-Babjat al-Saniyya fi Adab al-Tariqat al-'Aliyyat al-Khalidiyyat al-Naqshbandiyya, al-Maṭba'at al-Maymana, Cairo, n.d.

Al-Khalidy, Muhammad Waly, Inilah Risalat Adab Dhiker Ism al-Dhat dalam Tariqat Naqshbandiyya, Shirkat Banda Aceh,Aceh, 1900.

Al-Kurdy, Muhammad Amin, Al-Ijäbat al-Rabbaniyya, Maṭba'at alSa āda, Cairo, n.d.

—, Kitāb Tanwìr al-Qulüb fi Mu'āmalat 'Ālam al-Ghuyūb, Shirkah Bungkul Indah, Surabaya, 1980.

—, Kitāb al-Mawāhib al-Sarmadiyya fi Manāqib al-Naqshbandiyya, Maṭba'at al-Sa'āda, Cairo, $1329 \mathrm{H}$.

Landman, N., "Sufi Orders in the Netherlands: their Role in the Institutionalization of Islam", in: W.A.R. Shadid and P.S. van Koningsveld (eds.), Islam in Dutch Societies: Current Developments and Future Prospects, Kok Pharos, Kampen, 1992.

Lings, Martin, Syaikh Ahmad al-Alawi: Wali Sufi Abad 20, trans. Abdul Hadi W.M., Mizan, Bandung, 1989.

Muhaiyaddeen, Bawa, Islam \&World Peace: Explanations of a Sufi, the Fellowship Press, Philadelphia, 1987. 
Nasr, Seyyed Hossein, "Foreword", in: Hisham Kabbani, The Naqshbandi Sufi Way: History and Guidebook of the Saints of the Golden Chain, Kazi Publications, Inc, Chicago, 1995.

Netton, Ian Richard, Sufi Ritual: the Parallel Universe, Curzon Press, Richmond, 2000.

—, Sufi Essays, Allen and Unwin, London, 1972.

—, Traditional Islam in the Modern World, KPI, London, 1987.

Shadid, W.A.R. and PS. van Koningsveld, "Religieuze Therapie bij Moslims in Nederland" in: Moslims in Nederland: minderheden en religie in een multiculturele samenleving, Samson Stafleu, Alphen aan den Rijn, 1997.

Shah, Idries, The Sufis, the Octagon Press, London, 1977.

Sirriyeh, Elizabeth, Sufis and Anti Sufis: The Defence, Rethinking and Rejection of Sufism in the Modern World (excerpts are available online on www.amazo.com $/ 9 \mathrm{p} /$ reader/, being accessed on April 4, 2004).

Togan, Isenbike "The Khafi, Jahri Controversy in Central Asia Revisited", in: Elizabeth Ozdalga (ed.), Naqsbbandis in Western and Central Asia: Change and Continuity, Swedish Research Institute in Instanbul, Istanbul, 1999.

Werbner, Pnina, "Stamping the Earth with the Name of Allah: Zikr and the Sacralization of Space amongst British Muslims", in: Barbara Metcalf (ed.), Making Muslim Space in Europe, University of California Press, London, 1996. 